\title{
TERMÉKFEJLESZTÉSI FOLYAMATOK FEJLŐDÉSI IRÁNYAI
}

\author{
Soltész László \\ PhD hallgató, Miskolci Egyetem, Gép-és Terméktervezési Intézet \\ 3515 Miskolc, Miskolc-Egyetemváros, e-mail: solteszlaszlo1977@gmail.com \\ Berényi László \\ egyetemi docens, Miskolci Egyetem, Vezetéstudományi Intézet \\ 3515 Miskolc, Miskolc-Egyetemváros, e-mail: szvblaci@uni-miskolc.hu \\ Kamondi László \\ címzetes egyetemi tanár, Miskolci Egyetem, Gép- és Terméktervezési Intézet \\ 3515 Miskolc, Miskolc-Egyetemváros, e-mail: machkl@uni-miskolc.hu
}

\begin{abstract}
Absztrakt
A termékek és szolgáltatások folyamatos fejlödése magával vonja az öket létrehozó fejlesztési folyamatok modernizálásának igényét és lehetőségét. Ez a cikk a termékfejlesztési folyamatok fejlödését tanulmányozza, bemutatja azokat a föbb fejlődési irányokat, amelyek segítséget nyújtanak a jövö kulcspontjainak meghatározásában. A föbb iskolák, irányzatok kerülnek nagyvonalakban bemutatásra, majd egy áttekintö ábra a különbözö módszerek föbb ismérveiröl, eltéréseiröl a korábbiakhoz képest.
\end{abstract}

Kulcsszavak: termékfejlesztés, áttekintés, fejlödés, történelem

\begin{abstract}
The continuous improvement of the products and services implies the modernization of product development processes. In this paper, the improvement of product development methods is checked to find the main directions of improvement, which will help define further directions of evolution. We can see the leading schools and product development methods and a summary diagram with the main properties and improvement areas from previous methods.
\end{abstract}

Keywords: product development, review, improvement, direction, history

\section{Bevezetés}

A termékfejlesztési folyamatok körültekintő kialakítása, fejlesztése elengedhetetlen annak érdekében, hogy csökkenthessük a termékfejlesztés átfutási idejét, jobb, értékesebb terméket készíthessünk, valamint kontrolláljuk egy új termék piacra kerülésének kockázatait. Egy sikeres, hatékony termékfejlesztési folyamat megléte vagy hiánya kritikus pont az ipari teljesítmény tekintetében. A gyors és innovatív termékfejlesztési folyamat jelentős versenyelönyt biztosít a cégeknek [1].

A termékfejlesztési folyamatok fontossága ellenére, jelenleg nehézségekbe ütközik a vállalatoknak a termékfejlesztési folyamatok megtervezése vagy a kiválasztása az elérhető széles skálából. Amennyiben a vállalatok rosszul alakítják ki a folyamatokat, veszélybe sodorják a terméküket, azoknak versenyképességét, eredményességét, alkalmanként a piaci túlélését is. Jelenleg nincs megállapított kritérium a termékfejlesztési folyamatok összehasonlítására, szelektálására vagy megtervezésére. Egyetlen termékfejlesztési folyamat sem ideális minden körülmények között és 
minden vállalat számára [2]. Habár számtalan különböző tervezési modell és tervezési rendszer áll rendelkezésre, hogy támogassa a tervezési tevékenységet a tervezési folyamat különböző fázisaiban, egyik sem hatékony eléggé, hogy a vállalatok a saját termékeiket önállóan megtervezhessék és kifejleszthessék. A vállalatoknak törekedniük kell a saját iparágukhoz és müködési területükhöz, egyedi adottságokhoz illeszkedő, leginkább testreszabott termékfejlesztési folyamatok meghatározására. Kizárólag ebben az esetben tudnak versenyelőnyhöz jutni a versenytársakkal szemben, vagy akár csak szinten maradni a piac többi szereplőjéhez képest.

\section{Termékfejlesztési folyamatok fejlődése}

Az ipari vállalatok életében nagyon fontos a piacon jól müködő termékeinek a folyamatos továbbfejlesztése, tökéletesítése. Ezek a továbbfejlesztési folyamatok biztosítják azt, hogy az adott termék az életciklusa végéhez közeledve továbbra is vonzó maradhasson. A továbbfejlesztésnek köszönhetően, igazából egy új vagy „ráncfelvarrott” termék kerül a piacra, ami éppen annyira új, különböző az elöző terméktől, hogy a fogyasztók igényt érezzenek a régi termék cseréjére, új termék vásárlására. Napjainkban a vásárlói igény az új termékekre egyre intenzívebbé vált. A technológiai fejlődés hatására, az újabb és újabb müszaki megoldások, új funkciók egyre gyorsabban tűnnek fel a piacon, ez önmagában szükségessé teszi a termékek továbbfejlesztését, az új funkciók biztosítását. A vevők az új funkciók, új lehetőségek miatt egyre gyorsabban követelik az újdonságokat a termékekbe, azon vállalatok, akik nem tudnak lépést tartani a követelményekkel, kiesnek a piacról.

A piaci pozíció fenntartására, illetve javítására nem elegendő a meglévő termékek továbbfejlesztése, ráncfelvarrása, hanem teljesen új technológiákra épülö új termékek fejlesztése is szükségessé válik [3]. Természetesen a sebesség mértéke, az igény az újabb funkciók, termékek bevezetése függ az iparágtól, de alapvetően a termékek ráncfelvarrása, továbbfejlesztése napjainkban „csupán” az új termék fejlesztési idejét kitöltő új termék szerepét tölti be, ideglenesen kielégítve a vevői igényeket.

Összességében a világ, a piac, a vevői igények felgyorsulása miatt folyamatos az igény az új termékfejlesztési folyamatok felgyorsítására, a termékek gyorsabb piacra jutásának érdekében. A termékfejlesztési projektek sebessége nem csupán vevői igény, illetve áttételesen vevői igény, ami a vállalat vezetésének a vállát nyomja a befektető részéről. Az a vállalat, amelyik gyorsabb a fejlesztésben az könnyedén piacvezető pozícióba kerülhet, amikor az általa biztosított termékek, technológiák lesznek az iránymutatóak a követő vállalatok számára [4]. Ugyanakkor - ami a befektetők és a vállalatvezetés számára talán az elsődleges szempont - belátható, hogy a piaci bevezetés, mögötte pedig a termékfejlesztési projekt gyorsasága közvetlenül hatással van az új termék profitabilitására, megtérülésére és pénztermelő képességére. Mivel a vállalatok teljesítménymérőszámai szinte kizárólag az éves, illetve negyedéves eredmények értékelésén alapulnak, a gyorsabb piacra jutás közvetlenül javítja, míg a projekt esetleges késése vagy eleve lassú sebessége rontja az adott negyedév vagy pénzügyi év eredményét, aminek hatása tükröződik a befektetői bizalomban, sőt akár a tőzsdei árfolyamokon.

\section{A termékfejlesztési folyamatok fejlődési pályája}

Az integrált termékfejlesztési folyamatok eredetét 1985-re tehetjük, amikor Fredy Olsson megjelent az első integrált termékfejlesztési elvét taglaló publikációjával Stockholmban [5]. Meerkamm és Ottosson [3] [6] rendszerezték a folyamat első megjelenését, illetve különböző fejlődési variációit (1. ábra). Napjainkban a termékfejlesztési folyamatok ezeknek az integrált termékfejlesztési 
folyamatoknak az alapjaira épülnek. Természetesen nagy hangsúlyt kap, illetve könnyítést jelent a számítástechnikai, IT eszközök fejlődése. A modern termékfejlesztési folyamatokban a projekt menedzsment, különösen a párhuzamosan futó projektek kezelése manapság a felhő alapú technológiák segítségével sokkal jobban kézben tartható, mint az 1980-as és 1990-es években, amikor az alapokat lefektették. Amennyiben a konstrukciós tevékenységekre fókuszálunk, a 3Ds tervező szoftverekkel és a CAD rendszerek fejlődésével a tervező mérnökök munkája is hatékonyabbá vált. A PLM rendszerek lehetővé teszik és segítik a nagyobb mérnökcsoportok párhuzamos munkáját mind térben, mind időben az adott fejlesztési projektekben. A fenntartó mérnökség és az új termék fejlesztési csapat együttmüködve, tiszta keretek között tud egymás mellett, illetve egymást támogatva tevékenykedni.

A párhuzamos tevékenységek (Simultaneous Engineering) és a dinamikusan változó projekt követelmények (természetesen adott és kontrollált keretek között) egyre nagyobb teret enged az agilis projektmenedzsmentnek, illetve a SCRUM módszerek megjelenésének, nem csupán az IT szektorban, de egyéb termékfejlesztési területeken is. Az adott rövid távra tervezett részfeladatok megoldása, kidolgozása teret biztosít a további lehetséges változásoknak, ugyanakkor a projekt hatékonysága is megmarad, sőt fejlődik.

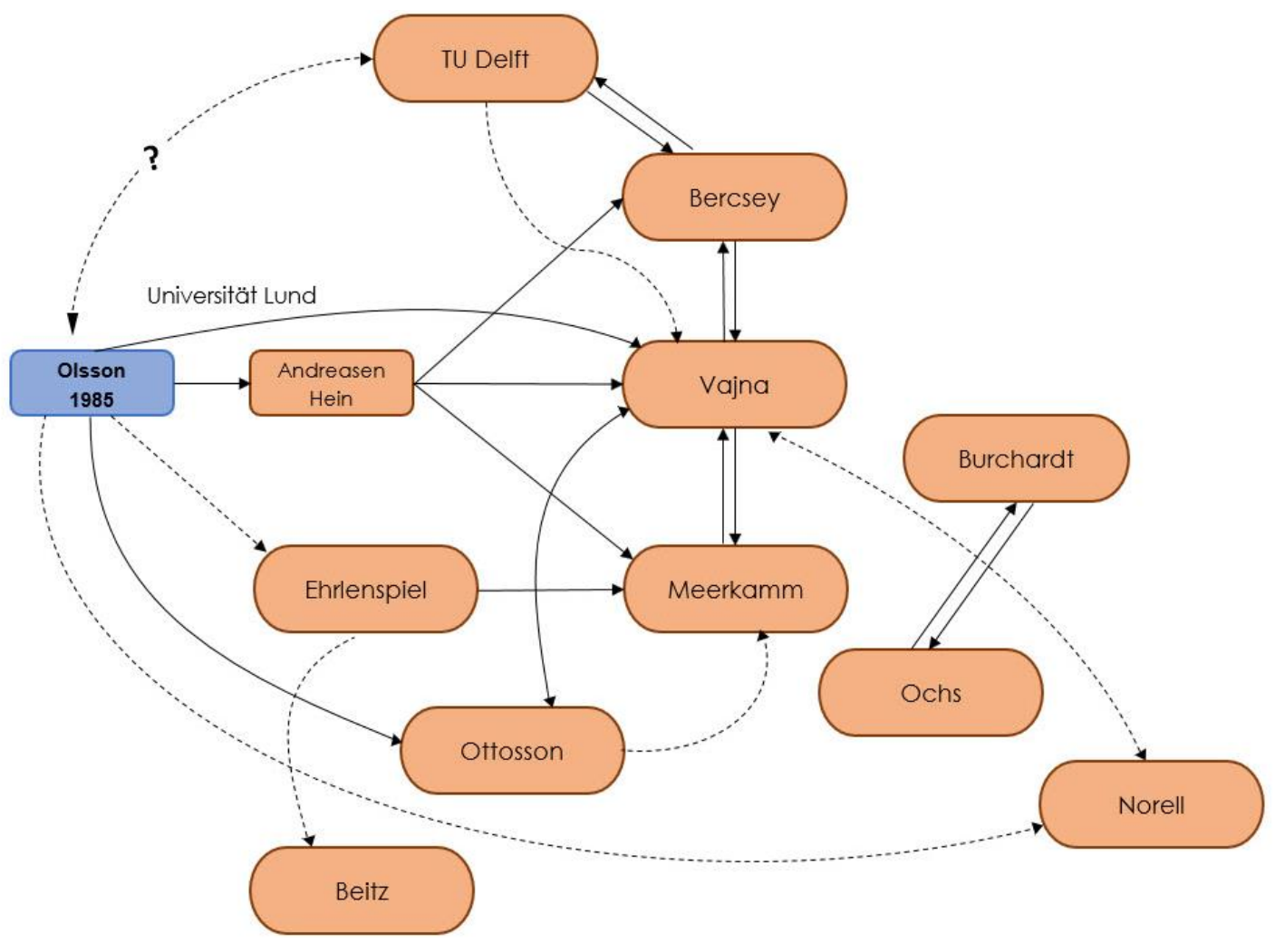

1. ábra. Integrált termékfejlesztési folyamatok fejlödése [3][6]

\subsection{Integrált termékfejlesztés (Olsson, 1985)}

Olsson [5] a kifejezetten konstrukcióval foglalkozó termékfejlesztés mellé integrálta a termékfejlesztési folyamatba a projektmenedzsmentet, termelést és piaci elvárásokat. Az adott projekt 
fázisokhoz rögzítette a különböző funkciók által szállítandó feladatokat, munkacsomagokat. Itt jelentek meg először az integrált funkciók a szakirodalomban. A szerző eredményeit a gyakorlat igazolta az elmúlt évtizedekben. Ma már vitán felüli, hogy a termékfejlesztés sikeressége csak (kis) részben múlik a termékfejlesztő mérnökök munkáján, kreativitásán, pontosságán. A sikeresség szempontjából kritikus a kapcsolódó társfunkciók szerepe és teljesítménye (2. ábra).

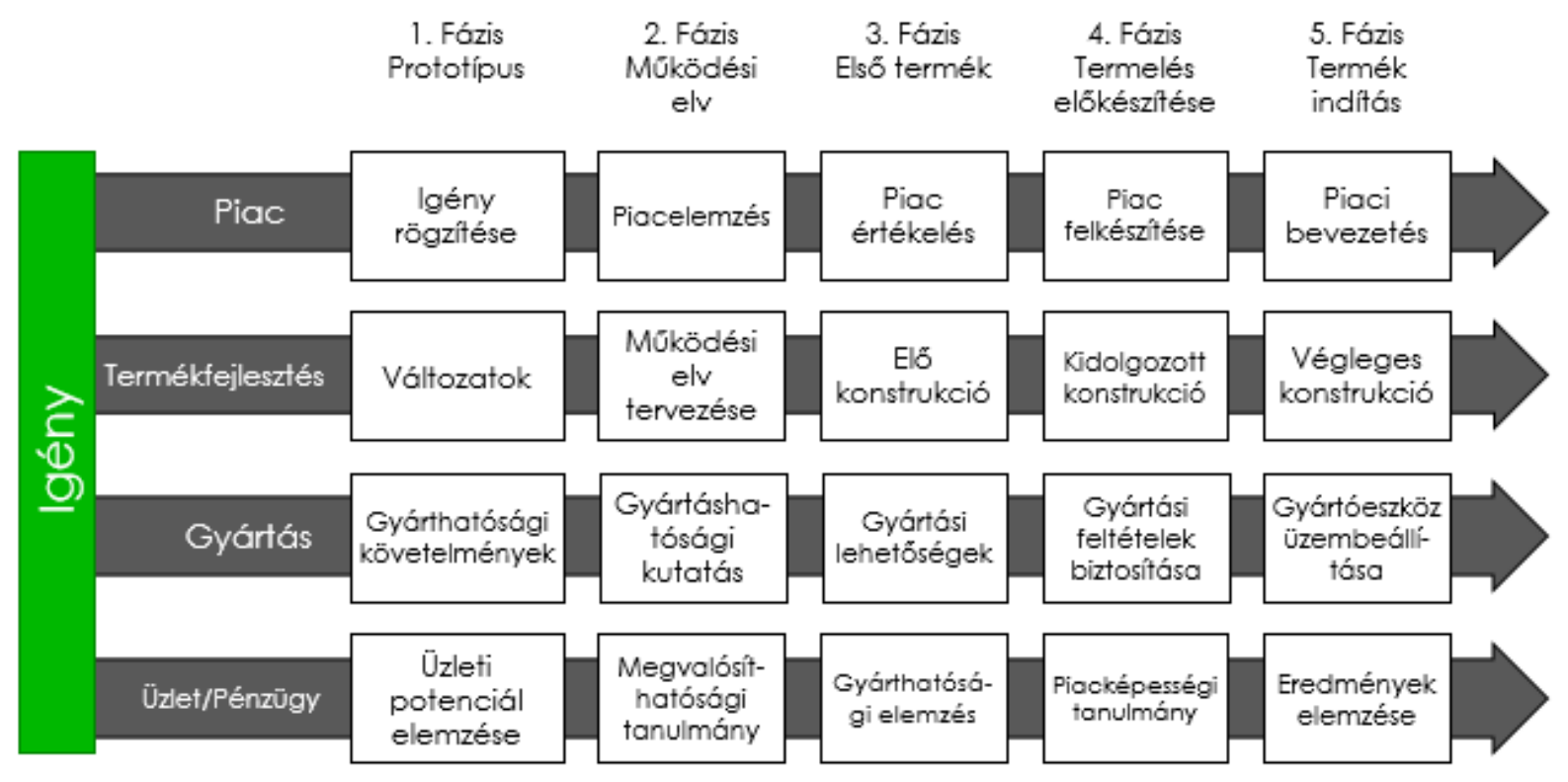

2. ábra. Integrált termékfejlesztési modell, Olsson [5]

\subsection{Integrált termékfejlesztési modell (Andreasen és Hein, 1987)}

Andreasen és Hein [7] tovább fejlesztette Olsson első modelljét az integrált termékfejlesztésre vonatkozva (3. ábra). Az általuk végzett fejlesztés alapját az az igény adta, hogy a termékfejlesztési folyamatban megjelent egyre nagyobb számban a különböző variánsok, alternatívák kidolgozása a különböző termék konfigurációkhoz. A termékváltozatok, részletek nagyon magas szintre emelkedtek. Párhuzamosan a számítástechnikai eszközök, az adatbázisok, adatbázis kezelő szoftverek is megjelentek, alkalmazhatóvá váltak, segítve a jelentősen megnövekedett adatok átláthatóságát, kezelhetőségét. A CAD rendszerek már egyre kifinomultabbá és használhatóvá váltak ebben az időben. A digitális rajz, modell tárolás nagy helyzeti előnyt jelentett, kombinálva a CAM rendszerekkel. A raktározás és karbantartás igényének szempontjából pl. egy autógyártónál a másoló marókhoz tárolt sablonok és a digitálisan tárolt modellek különböző igényeit. Náluk három alapvető résztvevő jelenik meg a folyamatábrában. A marketing, fejlesztés és a gyártás [7]. Az üzleti/pénzügyi terület nincs közvetlenül jelen a modellben, hanem az, mint alapvető eleme a projektnek, illetve a projekt kimenetének, mint üzleti siker jelenik meg. Nagy hangsúlyt fektetnek a marketingtöl érkező piaci igényeknek megfelelő termék kifejlesztésére, ugyanakkor a fejlesztésnek szintén figyelembe kell venni, illetve módosítani a termék konstrukciót a termelés igényeinek megfelelően a megfelelő gyárthatóság és költséghatékonyság miatt. 


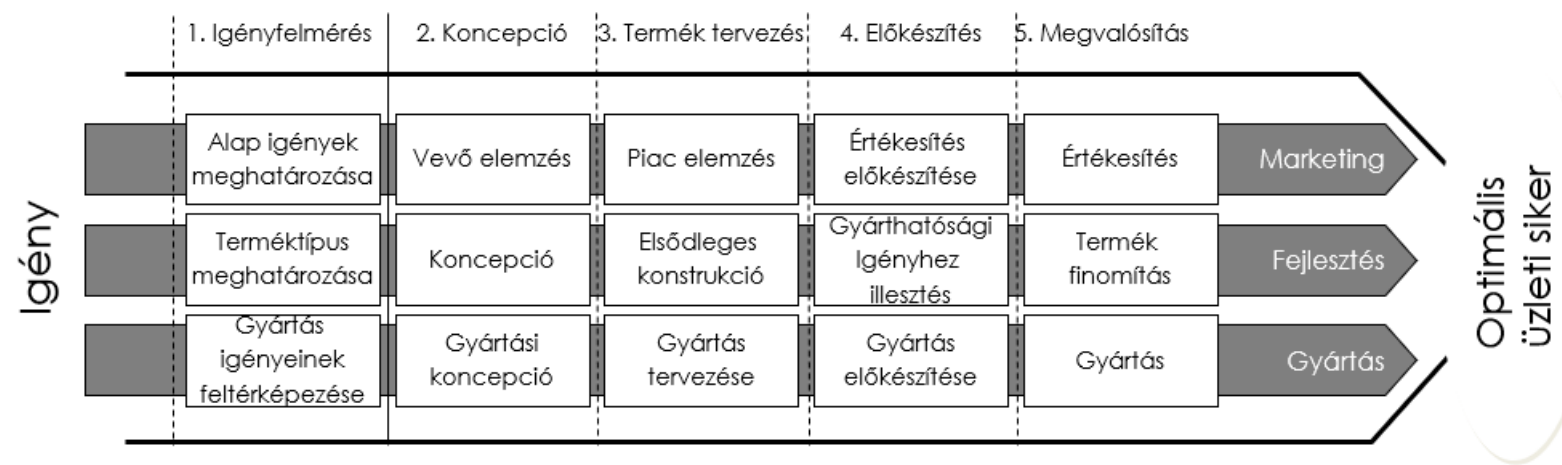

3. ábra. Integrált termékfejlesztési modell, Andreasen és Hein [7]

\subsection{Integrált termékfejlesztési modell (Ehrlenspiel, 1990)}

Ehrlenspiel a termékfejlesztési modelljében (4. ábra) a teljes szervezeti együttmüködés oldaláról közelítette meg a folyamatot. „A rutin alapú szervezeti munkaelosztástól az elkötelezett közösségig” [8]. A silókként múködő különböző osztályok helyett együttmüködő szervezetek kialakítása a kulcsa a modellnek. A projekt csapatban a különböző osztályok, különböző funkciók képviselői dolgoznak együtt egy csapatként a közös cél érdekében. A feladatokat közösen, egymást támogatva oldják meg az „átdobálás” helyett. A szervezeti felépítés mellett a funkciók fizikai elhelyezésére is találhatunk iránymutatást. A külön osztályok, külön irodák helyett a közös iroda, a termékfejlesztéshez tartozó funkciók együtt ülése is az iránymutatások között szerepel, egy légterü, közös irodákban.

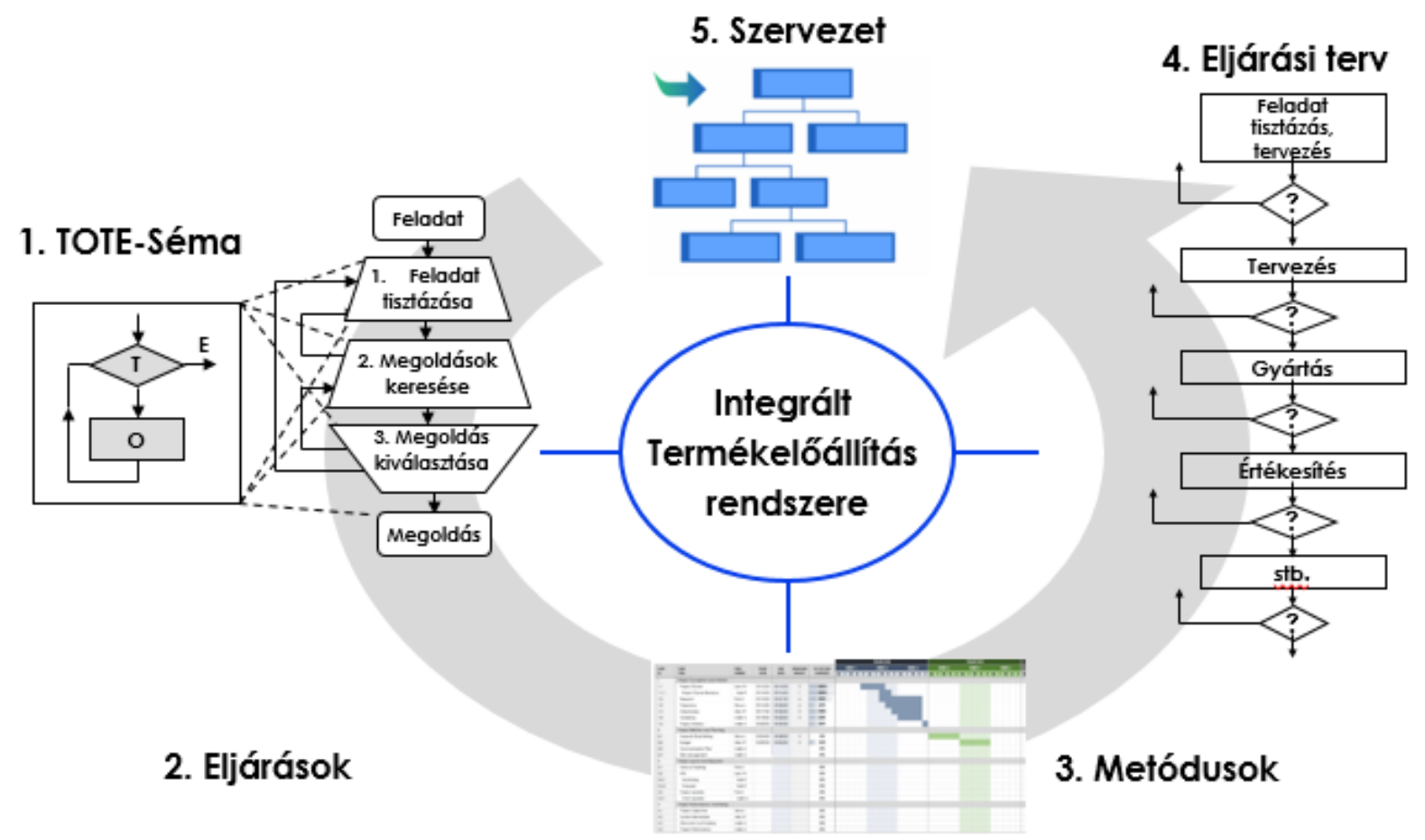

4. ábra. Integrált termékfejlesztési modell, Ehrlenspiel 1990 [8] 


\subsection{Integrált termékfejlesztési modell (Meerkamm, 1996)}

Meerkamm [6] 1996-ban mutatta be az általa tovább gondolt integrált termékfejlesztési modellt (5. ábra). Az általa megfogalmazott fó irányelvek:

- Alap koncepció: X-re tervezni, ahol X a teljes termék élettartam minden területe, előtérbe helyezve a felhasználást.

- A tervezésbe bevonni a vevőket, beszállítókat és minden szükséges szakértőt a pontos termékspecifikáció megfogalmazásába.

- Ennek a szakértő csoportnak a tudását használni a teljes tervezési és megvalósítási folyamatban.

- Olyan termék létrehozása, ami már közvetlenül, először kielégíti a követelményeket és időben elkészül a termékfejlesztési projekt időterv alapján ,just in time"-ban.

- Digitális támogatás: Mérnöki munkahely támogatva különböző IT eszközökkel (3D szoftver, adattárolás, változáskövetés stb.) [9].

1993-ban az internet szabad felhasználása további löketet, erőt adott a digitális fejlődésnek. A korábban már használt IT eszközök sokkal könnyebben, mindenki által elérhetően kapcsolódhattak, az információ és az adatmegosztás egyre egyszerübbé vált.

Az általa megfogalmazott irányelveket, hosszú évekig a gyakorlatban is jól alkalmazhatók. A beszállítók bevonása a termékfejlesztési projektekbe, illetve az együttmüködés már a fejlesztési szakaszban elengedhetetlen. A folyamatos költségcsökkentés nyomás miatt a beszerzési osztályok, illetve az R\&D ezekben a pontokban érdekellentétbe kerülnek, emiatt sok vállalat nem képes megvalósítani ezt a lépést ezért hátrányba kerülnek. Ezekben az esetekben nagyon fontos az elején tisztázni az érintett felek között a design tulajdonjogának kérdéseit, esetlegesen külön fejlesztési költség elszámolását a beszállító és a vállalat között. Ez a módszer a későbbiekben segíthet a lehetséges beszállítóváltások korrekt, gyors levezetésében.

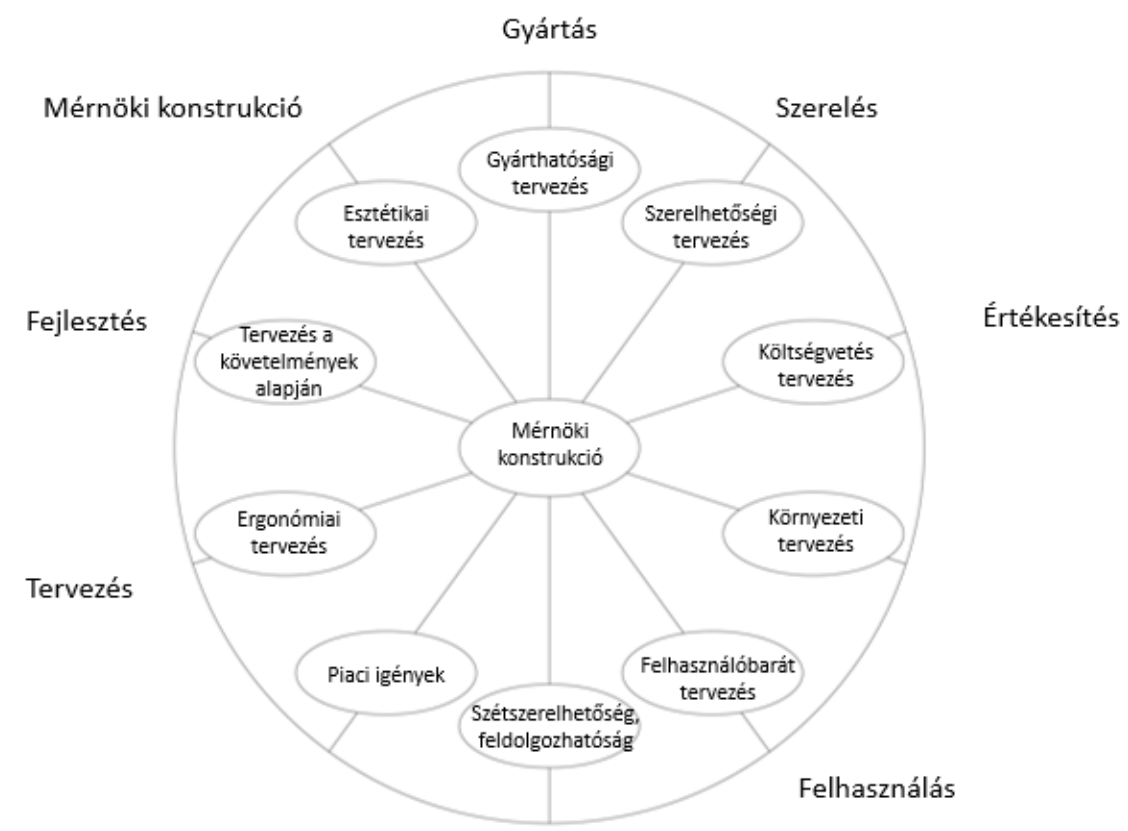

5. ábra. Termékfejlesztésre hatást gyakorló termékélettartam tényezök [6] 


\subsection{Integrált dinamikus termékfejlesztési modell (Ottosson, 1997)}

Ottosson modellje szintén az integrált együttmüködés jegyében született meg. A teljes elvégzendő feladatokat a különböző funkciók bevonásának arányában ábrázolja a diagrammján (6. ábra) [3] [10]. A különböző funkciók a projekt állásának megfelelően, a feladatok mennyiségének függvényében a szükségességnek megfelelő időt és munkát töltenek. Az idő függvényében ez dinamikusan változik. Nagyon fontos a megfelelö fejlesztőmérnökök kiválasztása a feladathoz, de talán még fontosabb a megfelelő projektvezető, aki megfelelően tudja kezelni az egyedi igényeit, adottságait a fejlesztőknek. A projektvezető támogatása, felhatalmazása a felsővezetés részéről alapvető fontosságú. Amennyiben a felettes testületek döntésükben elutasítják a projektvezető javaslatait, motivációvesztés következhet be. Ha a projektvezető már nem tekinti a projektet magénak, akkor az egész vezetése bizonytalanná válik, ezáltal nagy esélye lesz a projekt csúszásának, sikertelenségének.

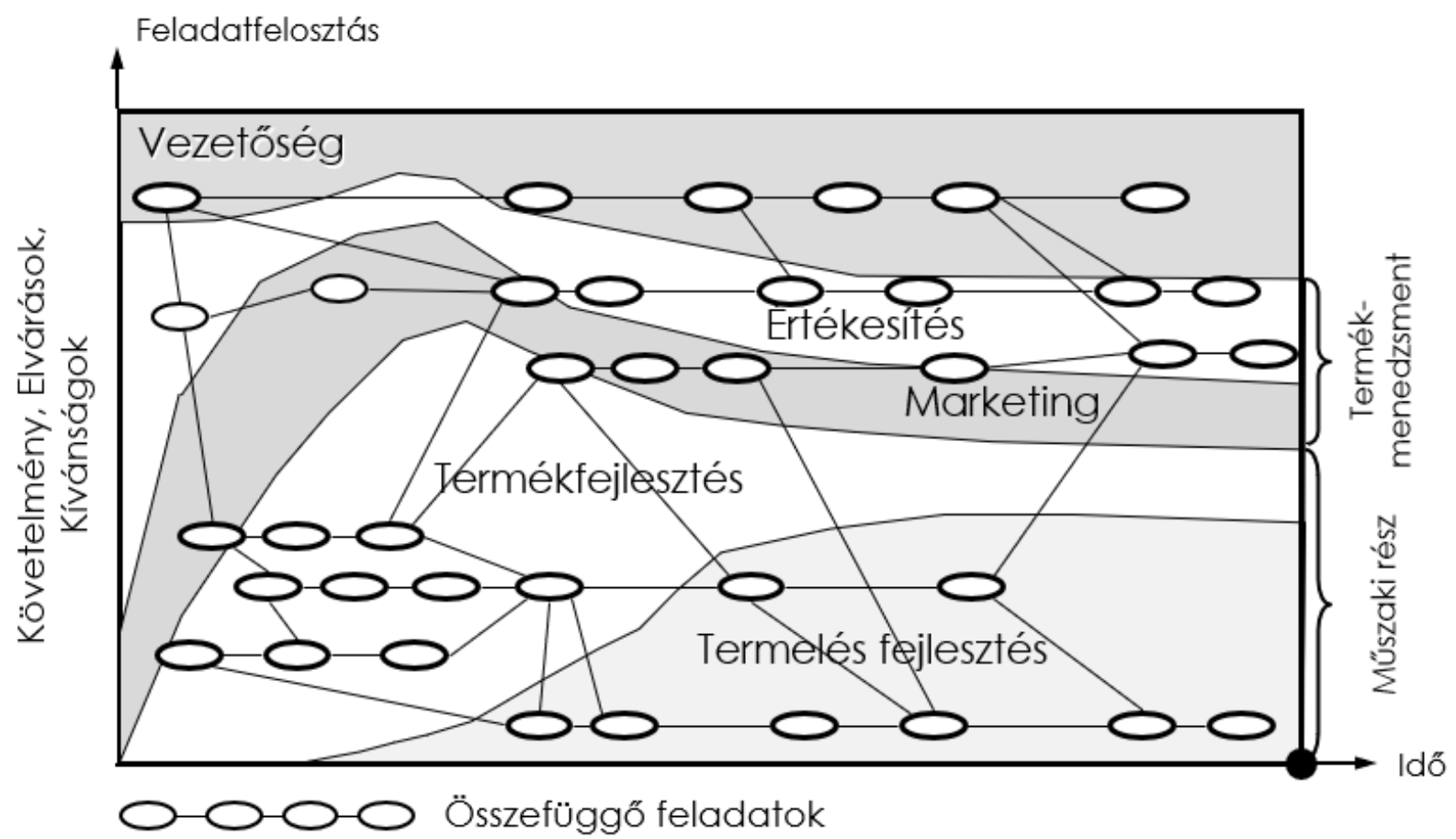

6. ábra. Integrált dinamikus termékfejlesztési modell [3]

\subsection{ADT eljárás modell (Bercsey és Vajna, 1994)}

Az ADT - Autogenetic Design Theory a biológia evolúciót állítja egymás mellé a termékfejlesztéssel. Minden munkafázisban több megoldás születik, ezek a megoldások versenyeznek egymással és a jobb életképesebb marad meg, illetve kerül továbbfejlesztésre [12]. Az ADT során a termékfejlesztés kezdetekor nem születik nagyon alapos, mindenre kiterjedő specifikáció, feltételezve azt, hogy a fejlesztés során a projekt célja változni fog a konstrukciós állapotok, fejlemények, valamint a dinamikusan változó igények miatt. Ezért a cél funkciók leírása és meghatározása történik meg a termékfejlesztés indításakor [11]. 


\subsection{Magdeburgi integrált termékfejlesztési modell (Buchardt és Vajna, 1996)}

A Magdeburgi integrált termékfejlesztési modell (7. ábra) hasonló vagy összehasonlítható Meerkamm modelljével [6]. Mindegyik esetben az ember központú fejlesztési filozófia az alapja a sikeres, versenyképes termékfejlesztési folyamatnak [13].

A modell integrálja a korábbi termékfejlesztési modellek különböző területeit:

- Figyelembe veszi a termék, piac, gyárthatóság, profitabilitás és menedzsment folyamatokat Olsson és Andreasen és Hein alapján.

- Ehrlenspiel által megfogalmazott folyamat ciklusok és munkatervezést.

- Együttmüködés az emberek, szervezetek, módszerek és technológiák között, ahogy Meerkamm módszerénél láthattuk.

- Figyelembe veszi a dinamikus termékfejlesztési folyamatot Ottosson alapján. [10]

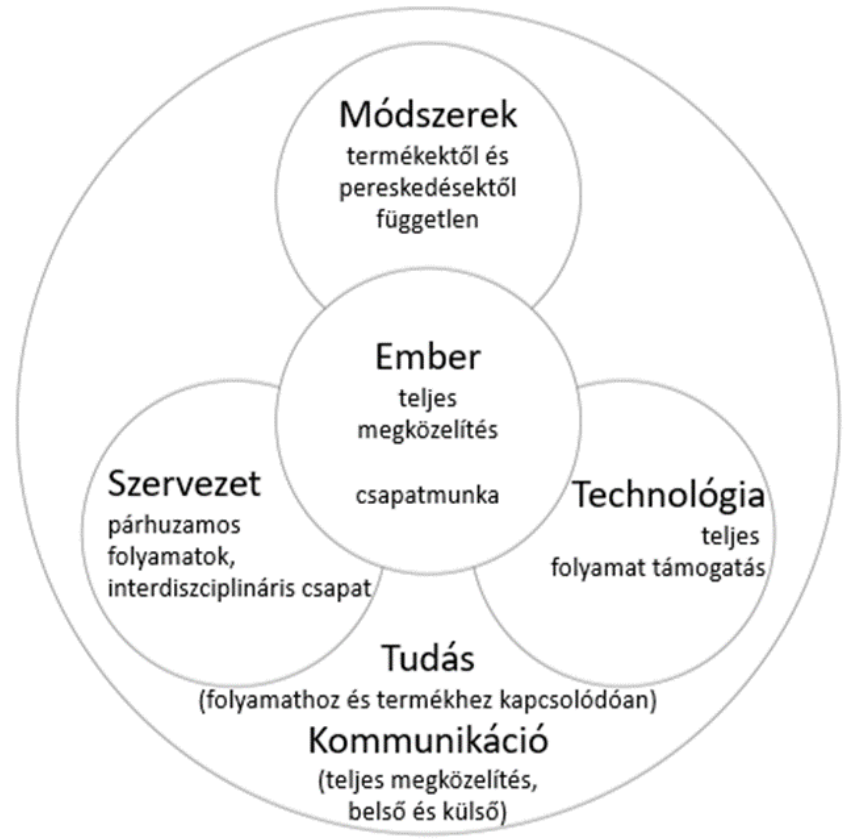

7. ábra. Az integrált termékfejlesztés Magdeburgi modellje [10]

\subsection{C-K tervezési módszer (Masson, Hatchuel és Weil, 1996)}

Egy teljesen másfajta megközelítést mutat be a C-K (koncepciók, tudás) tervezési módszer (8. ábra). Egy kötöttségektől sokkal mentesebb, innovatív kreatív módszert foglal magában ez a módszer vagy teória. Az egész módszer felfogható egy innovációs kihívásként, olyan jellegü fejlesztési feladatokat adhatunk vele a fejlesztőknek, amelyekre jelenleg nincsenek felkészülve, nem találkoztak még hasonló megoldással sem a gyakorlatukban. Kreativitásra, speciális problémamegoldásra, megoldáskeresésre ösztönzi a fejlesztőmérnököket a módszer. Túllép a kötöttségeken, a korábbi tapasztalatokon, megoldásokon, teljesen új mederbe terelve a konstrukciós megoldás javaslatokat. Sokkal több új, innovatív, kreatív termék megjelenésére van esély a módszer használatával [14]. 


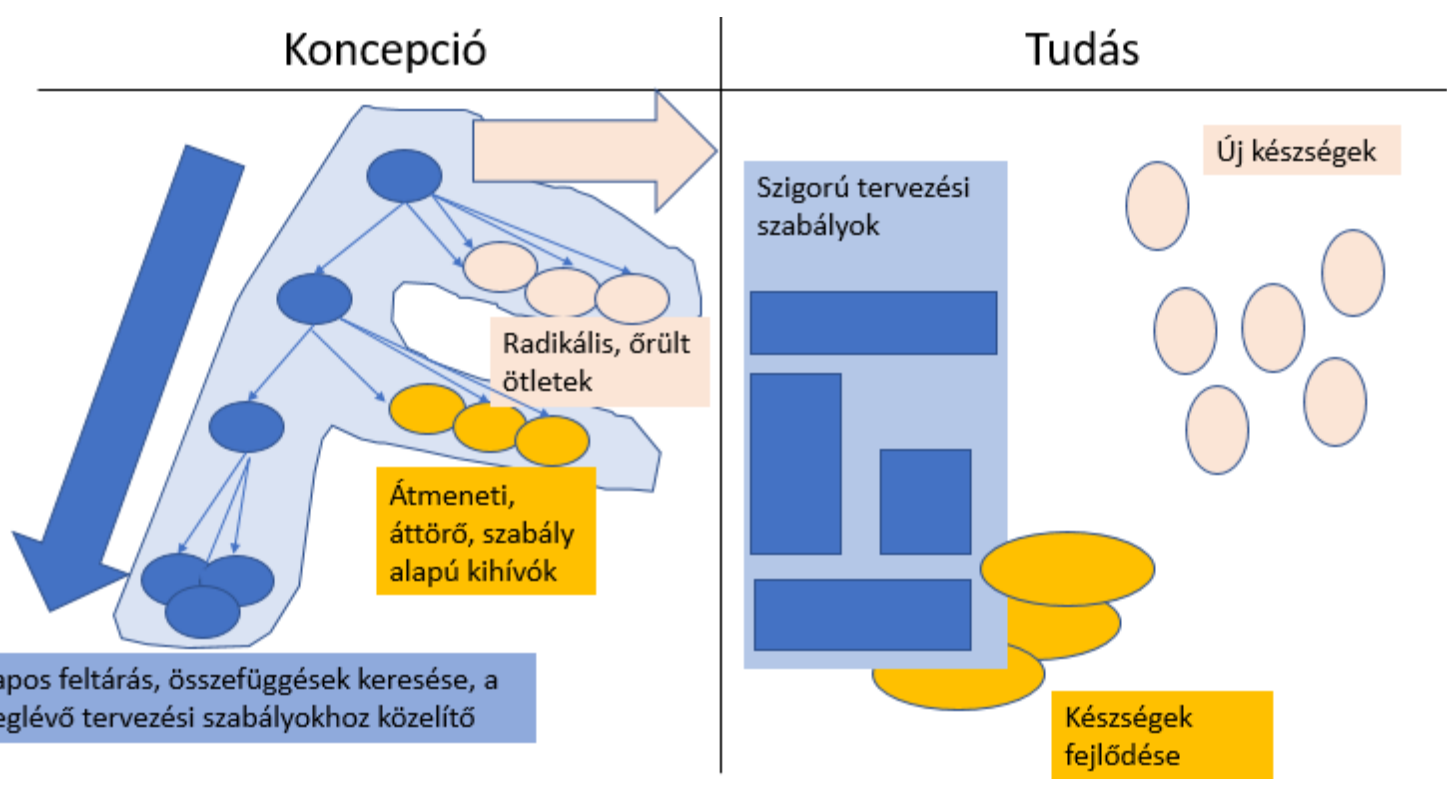

8. ábra. C-K tervezési módszer, szabály alapú tervezési rendszerben az új ötletek felhasználása [14]

\section{A termékfejlesztési folyamatmodellek összehasonlítása}

A fentebb megismert termékfejlesztési folyamatok összevetésénél láthatjuk, hogy néhány kivételtől eltekintve alapvetően hasonló felépítésüek. Bizonyos megközelítésekben eltérőek, illetve bizonyos területekre jobban vagy kevésbé fókuszálnak. Nyilvánvalóan a különböző iparági és akadémiai környezet hatásai érezhetőek az adott termékfejlesztési folyamatokon, valamint azok fejlödési irányain. Az 1. táblázat a vizsgált termékfejlesztési megközelítések főbb jellemzöit foglalja össze.

A kész térképen csoportosítottja a fejlődési irányokat (9. ábra). Összesen 4 csoportot sikerült azonosítani, amelyeket különböző színek különítenek el egymástól.

\section{5. Összefoglalás}

A termékfejlesztési folyamatok fejlödéstörténete során egyértelmüen megtalálhatóak a hasonló fejlődési irányultságok. Az elsődleges cél, az átfutási idők csökkentése, nem volt meglepetés, hiszen ez az alapja a gyorsabb piacra jutásnak, gyorsabb megtérülésnek, jobb piaci pozíciók elérésének.

A rugalmas specifikáció, illetve a projektek gyorsabb elkezdése szintén valamilyen szinten az átfutási idő csökkentésére irányul, ugyanakkor megmutatja az agilis projektmenedzsmentre történő törekvést, illetve rámutat arra, hogy teljesen merev célok, specifikációk esetén is lehet számítani változásokra a fejlesztés során felmerülö konstrukciós, technológiai és esetleges vevői igényváltozásokra.

Az integráció nagy előrelépés, amikor transzparensen, minden érintett fél tudásának a legmagasabb módon történő felhasználása valósulhat meg így. További nagy előnye az integrációnak, hogy a termékfejlesztés során felemerülő igények, problémák a teljes érintett funkciók közös megoldási javaslatai és ötletei alapján kerülhetnek gyors megoldásra. Az idők során a számítógépes rendszerek, internet, 3D szoftverek, PLM rendszerek napról napra egyre erősebbek, kényelmesebben használhatóak. Elengedhetetlen elemei a tervezői, termékfejlesztői munkának. Az egyre gyorsuló 
világban, ezeknek az IT eszközöknek a hatékonysága, használhatósága egyértelmű versenyelőnyt jelent, az azokat megfelelően használó vállalatok számára. Söt, már nem versenyelőnyként kell tekinteni az IT eszközökre és azok folyamatos fejlesztésére, hanem mint egy kötelező dologra, hiszen, aki nem tudja ezeket a lehetőségeket megragadni, menthetetlenül lemarad és elveszti versenyképességét, piaci részesedését.

1. táblázat. Termékfejlesztési folyamatok osztályozása

\begin{tabular}{|c|c|}
\hline \multicolumn{2}{|c|}{ Integrált Termékfejlesztés } \\
\hline \multirow{4}{*}{ Általánosan } & Csökken az igények begyũjtésének ideje \\
\hline & $\begin{array}{l}\text { Lehetséges legjobb módszer az igények, követelmények bevezetésére, } \\
\text { végrehajtására }\end{array}$ \\
\hline & Csôkken a terméfejlesztés ideje, a megtérülés \\
\hline & Javul a temék és folyamat minốség \\
\hline \multirow{7}{*}{ Olson, 1985} & Simultaneous engineering \\
\hline & Vevôi igények kielégtése a termék által \\
\hline & Front loading, párhozamos tevékenységek, idő \\
\hline & Meghatározott fázisok a hasonló feladatoknak \\
\hline & Projekt menedzsment bevoása termékfejlesztésbe \\
\hline & Csapatok integrálása, kūlōnbōzổ területekrôl (Value Engineering team) \\
\hline & Optimalizálás és költség csökkentés \\
\hline \multirow{4}{*}{ Andreasen and Hein, 1987} & Prediction: Market situation is stable \\
\hline & Párhuzamos és integrált folyamatok \\
\hline & $\begin{array}{l}\text { A termék élettartam figyelembevétele a termékfejlesztéskor, és a termékfejlesztés } \\
\text { figyelembevétel a termék élettartamnál }\end{array}$ \\
\hline & $\begin{array}{l}\text { Hangsúlyozza az ôsszes érintett bevonását, termelés elökészitését a gyártás inditás } \\
\text { elött }\end{array}$ \\
\hline \multirow{4}{*}{ Ehrlenspiel, 1990} & $\begin{array}{l}\text { Személyes integráció: a személy beleadja a teljesitményét és akarja szálitani a } \\
\text { projektet }\end{array}$ \\
\hline & $\begin{array}{l}\text { Információ integrációja: vevö, beszállitó integrációja, számítástechnikai } \\
\text { eszközök }\end{array}$ \\
\hline & Szervezet integrációja, lapos hierarchia, szeveztei struktúra és folyamat szervezet \\
\hline & Tervezés, elökészités és költségkalkuláció \\
\hline \multirow{3}{*}{ Meerkamm, 1996} & Figyelembe veszi a teljes termék életciklust és jôvöbeni áttervezéseket \\
\hline & Rugalmas szervezeti kialakitás, lapos szervezet \\
\hline & Integrált IT megoldások \\
\hline \multirow{2}{*}{ Ottosson, 1997} & Rövidebb âtutási idö \\
\hline & Elsốdeges követlmények alapjản elindul a projekt, késöbb úgyis változik \\
\hline \multirow{3}{*}{$\begin{array}{l}\text { Magdeburgi modell, } 1996 \\
\text { Burchardt, Vajna }\end{array}$} & Embercentrikus \\
\hline & OSztályok kozottti egyenlő egyūttmũkodés \\
\hline & Dinamikus szervezet, párhuzamos tevékenységek \\
\hline \multirow{4}{*}{ C-K Design elmélet 1996} & $\begin{array}{l}\text { Olyan konstrukció kihivásokra is adhat megoldást, ami a tradicionális fejlesztésben } \\
\text { nem }\end{array}$ \\
\hline & Magasabb szintü kreativitás \\
\hline & Kutató, felfedezö megoldások \\
\hline & Több megoldási javaslatot alkalmaz, nincsenek design jellegũ kơtôttségek \\
\hline \multirow{4}{*}{ Autogenetic Design Elmélet 1994} & Biológiai evolứció és a termékfejlesztés analógiaja \\
\hline & Több altemativa keröl kidolgozva a fázisokban, ezek versenyeznek egymással \\
\hline & Leirás és definíió a cél funkciókra \\
\hline & A specifikáció a projekt során változik, ezért nem fontos az elején fagyasztva lennie \\
\hline
\end{tabular}




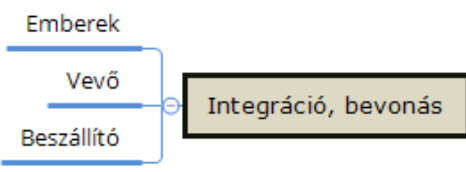

Rugalmas specifikáció, vevöi igények általi vezérlés

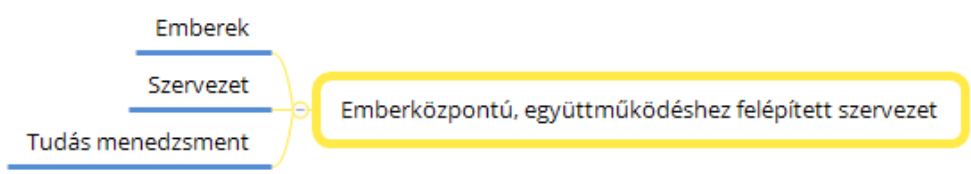

9. ábra. Termékfejlesztési folyamatok historikus fejlődési iránya

Az emberközpontúság szintén egy nagyon fontos eleme a termékfejlesztési folyamatok fejlődési ívének. Egyszerüen belátható, hogy a motivált, jól együttmüködő, megfelelő keretek között tevékenykedő mérnökök, illetve a teljes fejlesztési projekt személyzet sokkal eredményesebb és hatékonyabb tud lenni. Ez magában foglalja a projekt menedzsment fontosságát, elsődlegesen a projektvezető felhatalmazását, motiváltságát, képességeit. Nagyon fontos továbbá a közvetlen fejlesztőmérnökök tudása, hozzáállása a fejlesztéshez. Mennyire kreatívak, motiváltak, mennyire érzik magukénak a projektet, a terméket. Napjainkban a felgyorsult körülmények hatására a vállalatoknak, projektvezetőknek figyelembe kell venni az alkalmazottak nagyobb mértékü fluktuációját. Természetesen különböző megoldásokkal minden vállalat törekszik a kollégák megtartására, a fluktuáció csökkentésére, de sokkal nagyobb mértékben jellemző, mint a múltban. Ennek kapcsán külön figyelmet érdemel a tudásmenedzsment, a tudás összegyüjtése, tárolása, illetve a megoszthatósága, elérhetősége a következő kollégák számára.

A termékfejlesztési folyamatok jövőbeli fejlődési irányára lehet következtetni a múltbeli evolúcióból. Az alapvető fejlődési célok, mint a piacra jutási idő csökkentése, piaci részesedés szerzése, növelése, mindez annak érdekében, hogy a vállalat nagyobb profitot termelhessen, csupán egy célként vagy másodlagos eredményként fognak megjelenni a jövőben. Az emberközpontúság, a motivált csapatra épülő, őket segítő fejlődési irány kombinálva az integrációs törekvésekkel, tudásmenedzsmenttel, az IT eszközök által biztosított adatbázisokkal, felhő alapú tudástárolással, megosztással fogja meghatározni a termékfejlesztési folyamatok jövőjét.

A másik nagyon fontos irány, a folyamatok dinamikájának a fejlődése. A nagyon gyorsan, akár a fejlesztés közben változó vevői követelményekre vagy a fejlesztések során különböző akadályokra történő gyors reakció az, ami a fö ismérve lesz a jövő hatékony és minden körülmények között használható termékfejlesztési folyamatának.

\section{Köszönetnyilvánítás}

A cikkben ismertetett kutató munka KDP-2020 jelü „Kooperatív Doktori Program” részeként az Innovációs és Technológiai Minisztérium segítségével, a Nemzeti Kutatási, Fejlesztési és Innovációs Alapból biztosított támogatással valósul meg. 


\section{Irodalom}

[1] Jachimowicz, F.: Industrial-academic partnerships in research, 2000 Chemical Innovation, September, pp.17-20.

[2] Unger, D. W., Eppinger, S. D.: Comparing product development processes and managing risk, 2009 Int. J. Product Development, Vol. 8. No. 4 https://doi.org/10.1504/IJPD.2009.025253

[3] Ottosson, S.: Dynamic product development - DPD, 2004 Technovation 24(3):207-217, Linköping University, Sweden https://doi.org/10.1016/S0166-4972(02)00077-9

[4] Szakály, D.: Innovációmenedzsment 2013, Miskolci Egyetem Gazdaságtudományi Kar

[5] Olsson, F.: Integrerad Produktutveckling -Arbetsmodel, 1985 Series 21 Produktutveckling, Sveriges Mekanförbundet, Stockholm

[6] Meerkamm, H.: c, 1994 S. 1-13. VDI-Bericht. VDI-Verlag, Düsseldoorf

[7] Andreasen, M. M., Hein, L.: Integrated product development, 1987 IFS

[8] Ehrlenspiel, K.: Integrierte Produkterstellung - Organisation-Methoden-Hilfsmittel, 19913. Münchener Kolloquium https://doi.org/10.1007/978-3-662-10930-4_6

[9] Ehrlenspiel, K., Meerkamm, H.: Integrierte Produktentwicklung, 2007 Carl hanser Verlag GmbH \& Co.

[10] Vajna, S., Burchardt, C.: Modelle und Vorgehensweisen der Integrierten Productentwicklung, 2014 Integrated Design Engineering, pp. 3-50. https://doi.org/10.1007/978-3-642-41104-5_1

[11] Bercsey, T., Vajna, S.: Ein Autogenetischer Ansatz für die Konstruktionstheorie 1994 CAD-CAM Report 13, vol. 2, pp. 66-71 and 14 vol. 3, pp. 98-105

[12] Vajna, S. (ed.): Integrated Design Engineering - Interdisciplinary and Holistic Product Development. 2020 Springer Nature Heidelberg https://doi.org/10.1007/978-3-030-19357-7

[13] Naumann, T.: Adaptive SYSTEMMANAGEMENT. Ein Ansatz für die Planung und Steuerung von Produktentwicklungsprozessen 2005 Dissertation Otto-von-Guericke-Universität Magdeburg

[14] Le Masson, P., Weil, B., Hatchuel, A.: Design Theory-Methods and Organization for Innovation 2017 Springer International Publishing AG. ISBN 978-3-319-50277-9 